\title{
METABOLIC SYNDROME AND ENDOTHELIN-1 MEDIATED VASOCONSTRICTOR TONE IN OVERWEIGHT/OBESE ADULTS
}

\author{
Natalia G. Rocha ${ }^{1,4}$, Danielle L. Templeton ${ }^{1}$, Jared J. Greiner ${ }^{1}$, Brian L. Stauffer ${ }^{1,2,3}$, and \\ Christopher A. DeSouza ${ }^{1,2}$ \\ ${ }^{1}$ Integrative Vascular Biology Laboratory, Department of Integrative Physiology, University of \\ Colorado, Boulder, CO 80309 \\ ${ }^{2}$ Integrative Vascular Biology Laboratory, Department of Medicine, University of Colorado Denver \\ and the Health Sciences Center, Aurora, CO 80045 \\ ${ }^{3}$ Integrative Vascular Biology Laboratory, Denver Health Medical Center, Denver, CO 80204 \\ ${ }^{4}$ Integrative Vascular Biology Laboratory, Department of Physiology and Pharmacology, \\ Fluminense Federal University, Niteroi, RJ, 24210-130
}

\begin{abstract}
Objective-To determine whether endothelin (ET)-1 vasoconstrictor tone is greater in overweight and obese adults with the metabolic syndrome (MetS).
\end{abstract}

Materials/Methods-Forty overweight/obese middle-aged and older adults (age: $43-71$ years; BMI: $25.1-36.9 \mathrm{~kg} / \mathrm{m}^{2}$ ) were studied: 20 without MetS (13 M/7 F) and 20 with MetS (13 M/7 F). MetS was established according to NCEP ATP III guidelines. Forearm blood flow (FBF; plethysmography) responses to intra-arterial infusion of selective $\mathrm{ET}_{\mathrm{A}}$ receptor blockade (BQ-123; $100 \mathrm{nmol} / \mathrm{min}$; for $60 \mathrm{~min}$ ) and non-selective $\mathrm{ET}_{\mathrm{A} / \mathrm{B}}$ receptor blockade (BQ-123 + BQ-788 [50 $\mathrm{nmol} / \mathrm{min}$ for $60 \mathrm{~min}]$ ) were determined.

\begin{abstract}
Results-In response to the selective $\mathrm{ET}_{\mathrm{A}}$ antagonism, there was a significant increase in forearm blood flow from baseline in both groups. However, the increase in forearm blood flow was significantly higher $(\mathrm{P}=0.03 ; \sim 45 \%)$ in the overweight/obese group with MetS than the group without MetS. In contrast, there were no significant group differences in FBF responses to nonselective $\mathrm{ET}_{\mathrm{A} / \mathrm{B}}$ receptor blockade. Peak vasodilator responses to nonselective $\mathrm{ET}_{\mathrm{A} / \mathrm{B}}$ blockade were $\sim 50 \%$ higher than baseline blood flow in the overweight/obese groups without and with MetS.
\end{abstract}

\footnotetext{
(C) 2014 Elsevier Inc. All rights reserved.

Correspondence: Christopher DeSouza, Ph.D. Integrative Vascular Biology Laboratory Department of Integrative Physiology University of Colorado 354 UCB Boulder, CO 80309 TEL: (303) 492-2988; FAX: (303) 492-6778 desouzac@ colorado.edu.

Publisher's Disclaimer: This is a PDF file of an unedited manuscript that has been accepted for publication. As a service to our customers we are providing this early version of the manuscript. manuscript will undergo copyediting, typesetting, and review of the resulting proof before it is published in its final citable form. Please note that during the production process errors may be discovered which could affect the content, and all legal disclaimers that apply to the journal pertain.

Disclosure: none

AUTHOR CONTRIBUTIONS

CAD and BLS conceived and carried out experiments. NGR, DLT and JJG carried out experiments and analyzed data. All authors were involved in writing the paper and had final approval of the submitted and published versions.
} 
Conclusion-MetS is associated with higher ET-1 vasoconstrictor tone in overweight/obese adults. The enhanced ET-1 vasoconstrictor activity with MetS is mediated by the $\mathrm{ET}_{\mathrm{A}}$ receptor subtype.

\section{Keywords}

Metabolic syndrome; endothelin-1; blood flow

\section{INTRODUCTION}

Overweight and obesity is associated with profound endothelial dysfunction, which is thought to contribute etiologically to the increased risk of cardiovascular disorders and events with excess adiposity. Indeed, we $(33,38)$ and others $(28)$ have shown that overweight and obese adults, independent of other cardiovascular risk factors, demonstrate significant impairments in endothelial vasomotor and fibrinolytic function. Metabolic syndrome (MetS) involves a clustering of cardiometabolic disorders, specifically hypertension, dyslipidemia, insulin resistance and hyperglycemia, that often coexists with excess adiposity; further heightening the cardiovascular risk burden in overweight and obese adults $(6,10,12)$. With the escalating prevalence of overweight and obesity, it is estimated that $\sim 35 \%$ of the US adult population have the MetS (21). This is alarming considering that the presence of the MetS confers a two- to four-fold increased risk of coronary artery disease (12) and a sharp rise in all-cause mortality (20). The mechanisms underlying the greater cardiovascular risk with the MetS, especially in overweight and obese adults, are not completely understood.

Endothelin-1 (ET-1) is a powerful endogenous vasoconstrictor peptide that is produced and released by the vascular endothelium. In addition to its role in the regulation of vascular tone, ET-1 has been linked to the pathogenesis of hypertension, heart failure and atherosclerotic vascular disease $(19,30)$. We have previously reported that ET-1 vasoconstrictor tone is elevated with increases in adiposity, contributing to diminished endothelium-dependent vasodilation and augmented cardiovascular risk in overweight and obese adults (38). The impact of the MetS on ET-1 system activity in overweight and obese adults is currently unknown. Accordingly, we tested the hypothesis that ET-1 mediated vasoconstrictor tone is higher in overweight/obese adults with MetS compared with overweight/obese adults free of MetS.

\section{METHODS}

\section{Subjects}

Forty overweight/obese middle-aged and older adults (age: 43-71 yrs; body mass index [BMI]: 25.1-36.9 kg/m²) were studied: 20 without MetS (13 M/7 F) and 20 with MetS (13 M/7 F). MetS was established according to the National Cholesterol Education Program (NCEP) Adult Treatment Plan (ATP) III criteria $(6,29)$. NCEP-ATP III criteria for MetS was used rather than other criteria such as the World Health Organization (39) or International Diabetes Federation (1) definition due to its greater strength in predicting CVD $(8,14)$. Sixteen of the 20 subjects in the MetS group met three of the NCEP-ATP III criteria 
and four of the 20 met four of the NCEP-ATP III criteria (average number of criteria met: $3.2 \pm 0.1)$. In the subjects without MetS, two subjects had two MetS characteristics, 12 subjects had one and six subjects met no MetS criteria. The subjects were sedentary, nonsmokers, nonmedicated (including vitamins), nondiabetic and free of overt cardiovascular disease as assessed by medical history, physical examination, resting and exercise electrocardiograms, and fasting blood chemistries. All of the women in the study were at least 1 year postmenopausal and had never taken or discontinued hormone replacement therapy $\geq 1$ year before the start of the study. Before participation, subjects provided written informed consent according to the guidelines of the University of Colorado, Boulder.

\section{Body Composition and Metabolic Measurements}

Body mass was measured to the nearest $0.1 \mathrm{~kg}$ using a medical beam balance. Percent body fat was determined by dual-energy X-ray absorptiometry (Lunar Radiation, Madison, WI). BMI and minimal waist circumference were measured according to published guidelines (13). Fasting plasma lipid and lipoprotein, glucose, and insulin concentrations were determined using standard techniques by the clinical laboratory affiliated with the University of Colorado, Clinical Translational Research Center. Insulin resistance was estimated using the homeostasis model assessment (HOMA-IR) derived from fasting glucose and insulin concentrations (18).

\section{Intra-arterial Infusion Protocol}

All studies were performed between 7:00 AM and 10:00 AM after a 10-hour overnight fast in a temperature-controlled room, as previously described by our laboratory (38). Briefly, a 5 -cm, 20-gauge catheter was inserted into the brachial artery of the non-dominant arm under local anaesthesia. Heart rate and arterial blood pressure were continuously measured throughout the infusion protocol. Forearm blood flow (FBF) at rest and in response to ET-1 receptor blockade was measured in both the experimental (nondominant) and contralateral (dominant) forearm by strain-gauge venous occlusion plethysmography (D. E. Hokanson, Bellevue, WA).

Following measurement of baseline FBF, BQ-123 (Clinalfa, AG), a selective ET $_{\mathrm{A}}$ receptor antagonist, was infused at a rate of $100 \mathrm{nmol} / \mathrm{min}$ for 60 minutes. FBF was measured every 10 minutes throughout the infusion period. The selected dose of BQ-123 has been shown to completely inhibit the $\mathrm{ET}_{\mathrm{A}}$ mediated vasoconstrictor effect of ET-1 in the human forearm of healthy adults (2). After 60 minutes of BQ-123 infusion, the FBF response to nonselective ET-1 receptor blockade was assessed by the co-administration of BQ-123 and BQ-788 (Clinalfa, AG) for an additional 60 minutes. FBF was measured every 10 minutes during the combined BQ-123 and BQ-788 infusion. BQ-788, a specific antagonist of ET $_{\mathrm{B}}$ receptors, was infused at a rate of $50 \mathrm{nmol} / \mathrm{min}$, a dose shown to effectively inhibit $\mathrm{ET}_{\mathrm{B}}$ receptors (2, $35)$. Due to limited drug availability, studies involving BQ-788 were performed in a subset of the total study population (12 of the 20 subjects without MetS and 12 of the 20 subjects with MetS). 


\section{Statistical analysis}

Differences in subject baseline characteristics were determined by between-groups analysis of variance (ANOVA). Group differences in FBF responses to BQ-123 and BQ-123+BQ-788, expressed as percent change from resting FBF, were determined by repeated-measures ANOVA. Relations between variables of interest were assessed by linear regression analysis. There were no significant gender interactions; therefore, the data were pooled and presented together. All data are expressed as mean \pm SEM. Statistical significance was set at $P<0.05$.

\section{RESULTS}

Table 1 presents selected subject characteristics. There were no significant differences in age, body mass, BMI, body fat, waist circumference, diastolic blood pressure, total and LDL-cholesterol between the groups. As expected, the metabolic syndrome criteria variables were significantly different in the MetS group, specifically: higher systolic blood pressure, triglycerides, fasting insulin concentrations, HOMA-IR and lower HDL-cholesterol. Table 2 presents the subject characteristics for the subgroup of adults who received non-selective ET receptor blockade (BQ-123 + BQ-788). Similar to the total population, metabolic syndrome criteria variables that were significantly different in the MetS group were: systolic blood pressure, triglycerides and lower HDL-cholesterol.

Baseline FBF was not significantly different between the groups. In response to BQ-123, FBF increased significantly in both groups from baseline. However, the vasodilator response to selective $\mathrm{ET}_{\mathrm{A}}$ receptor blockade (BQ-123) was higher $(\sim 45 \% ; \mathrm{P}<0.05)$ in the group with MetS (Figure 1). There were no significant correlates between the FBF response to BQ-123 and any anthropometric, hemodynamic or metabolic variables.

In contrast to selective $\mathrm{ET}_{\mathrm{A}}$ receptor blockade, there were no significant group differences in $\mathrm{FBF}$ responses to non-selective $\mathrm{ET}_{\mathrm{A} / \mathrm{B}}$ receptor blockade (Figure 2). The co-infusion of BQ-788 with BQ-123 resulted in significant further increases in FBF from that observed with BQ-123 alone. Peak FBF responses to nonselective $\mathrm{ET}_{\mathrm{A} / \mathrm{B}}$ blockade was $\sim 50 \%$ higher than baseline blood flow in the overweight/obese groups without and with MetS.

\section{DISCUSSION}

The novel findings of the present study are as follows: (1) selective $\mathrm{ET}_{\mathrm{A}}$ receptor blockade elicited a significantly greater vasodilator response in overweight/obese adults with MetS compared with overweight/obese adults without MetS; (2) non-selective $\mathrm{ET}_{\mathrm{A}}$ and $\mathrm{ET}_{\mathrm{B}}$ receptor blockade resulted significantly greater vasodilation than that produced by selective $\mathrm{ET}_{\mathrm{A}}$ antagonism in both groups; and (3) the vasodilator response to non-selective ET receptor blockade was not different between overweight/obese adults without or with MetS . Collectively, these findings indicate that MetS is associated with enhanced $\mathrm{ET}_{\mathrm{A}}$, but not $\mathrm{ET}_{\mathrm{B}}$, receptor mediated ET-1 vasoconstrictor tone in overweight/obese adults. To the best of our knowledge this is the first study to assess the influence of the MetS on ET-1 system activity in overweight/obese adults. We have previously reported that overweight and obesity, independent of other cardiometabolic risk factors, are associated with elevated ET-1 
bioavailability and augmented ET-1 vasoconstrictor tone mediated through the $\mathrm{ET}_{\mathrm{A}}$ receptor(38). The results of the present study significantly extend these findings by demonstrating that the presence of the MetS adversely influences the ET-1 system in overweight/obese adults.

The vascular effects of ET-1 are mediated by two distinct ET receptor subtypes; $\mathrm{ET}_{\mathrm{A}}$ receptors located exclusively on vascular smooth muscle and $\mathrm{ET}_{\mathrm{B}}$ receptors located on both the vascular smooth muscle and endothelial cells $(3,7,16)$. Binding of ET-1 to $\mathrm{ET}_{\mathrm{A}}$ and $\mathrm{ET}_{\mathrm{B}}$ receptors on vascular smooth muscle cells activates vasoconstriction. Conversely, activation of $\mathrm{ET}_{\mathrm{B}}$ receptors on endothelial cells stimulates the release of nitric oxide and prostacyclin inducing vasodilation $(15,19)$. Our findings indicate that the presence of the MetS in overweight/obese adults appears to preferentially affect the $\mathrm{ET}_{\mathrm{A}}$ receptor subtype. Although blockade of the $\mathrm{ET}_{\mathrm{A}}$ receptor produced a significant increase in $\mathrm{FBF}$ from baseline in both groups, the vasodilator response was much higher ( $45 \%)$ in subjects with MetS; indicative of greater $\mathrm{ET}_{\mathrm{A}}$ mediated ET-1 vasoconstrictor tone. The lack of group differences in the vascular responses with the addition of $\mathrm{ET}_{\mathrm{B}}$ receptor blockade argues against a MetS-related influence on the $\mathrm{ET}_{\mathrm{B}}$ receptor mediated vasoconstriction. In addition to excess adiposity, elevated $\mathrm{ET}_{\mathrm{A}}$ receptor mediated vasoconstriction has been shown in a number of cardiometabolic risk factors that are integral components of the MetS (2, 4, 17, 37). For example, elevations in blood pressure in both the prehypertensive (120/80-139/89 $\mathrm{mm} \mathrm{Hg}$ ) and hypertensive ( $\geq 140 / 90 \mathrm{~mm} \mathrm{Hg}$ ) range are associated with higher $\mathrm{ET}_{\mathrm{A}}$ receptor mediated vasoconstriction compared with normal blood pressure $(2,37)$. Moreover, we recently reported greater ET-1 vasoconstrictor activity via the $\mathrm{ET}_{\mathrm{A}}$ receptor in middle-aged adults with impaired fasting blood glucose (4). Thus, it is difficult to discern whether the negative influence of the MetS on $\mathrm{ET}_{\mathrm{A}}$ receptor mediated ET-1 vasoconstrictor tone is due to a specific MetS component or is a general consequence of the syndrome per se. Indeed, we have previously demonstrated that the MetS worsens the inflammatory and oxidative stress burden with overweight and obesity (32). Considering inflammatory and oxidative mediators have been linked to ET-1 system activation $(22,25,36)$ and $\mathrm{ET}_{\mathrm{A}}$ receptor activity (5), it is plausible these processes may also contribute to the MetS-related elevation in $\mathrm{ET}_{\mathrm{A}}$ mediated ET-1 vasoconstrictor tone.

The apparent lack of a MetS-related influence on the vascular response to concurrent $\mathrm{ET}_{\mathrm{A} / \mathrm{B}}$ receptor blockade was somewhat surprising. $\mathrm{ET}_{\mathrm{A} / \mathrm{B}}$ receptor antagonism has been shown to augment the vasodilator responses to selective $\mathrm{ET}_{\mathrm{A}}$ receptor blockade under hypertensive (2) and hyperglycemic (4) conditions, both major components of the MetS. In the present study, both groups demonstrated similar increases in FBF to BQ-123 + BQ-788 above that elicited by $\mathrm{BQ}-123$ alone; suggesting greater propensity for $\mathrm{ET}_{\mathrm{B}}$ mediated vascular smooth muscle vasoconstriction over $\mathrm{ET}_{\mathrm{B}}$ mediated endothelial vasodilation in overweight and obese adults without and with MetS. Lower $\mathrm{ET}_{\mathrm{B}}$ mediated vasodilator capacity is consistent with many studies detailing impaired endothelium-dependent vasodilator function with overweight and obesity $(28,31,34)$. While the vascular effects of $\mathrm{ET}_{\mathrm{B}}$ receptors appear to be influenced more by adiposity than the presence of the MetS, it should be noted that the hemodynamic and metabolic characteristics of our MetS subjects were not grossly abnormal. None of the subjects were hypertensive, diabetic or profoundly dyslipidemic. 
MetS-related differences in the vascular responses to nonselective $\mathrm{ET}_{\mathrm{A} / \mathrm{B}}$ receptor antagonism may emerge in overweight/obese adults with a clinically more remarkable atherogenic cardiometabolic risk profile.

There are a few experimental considerations regarding this study that deserve mention. Firstly, an inherent limitation with all cross-sectional design studies is the inability to discount the potential influence of genetic and/or lifestyle behaviors on study results. In an effort to minimize the effects of lifestyle behaviors and isolate the influence of the MetS on our outcome variables we studied overweight/obese (without and with MetS) of similar age who were nonsmokers, not taking any medication, and not habitually physically active. Moreover, we employed strict inclusion criteria to eliminate the confounding effects of clinically overt cardiovascular and metabolic diseases. Secondly, our study population was not gender equivalent, with only 14 of the 40 subjects ( 7 in each experimental group) being women. Although we observed no effect of gender in the present study, gender-differences in ET-1 system activity have been reported (27). Given the relatively modest number of women in our study, we are unable to be conclusive regarding possible gender interactions/ differences with MetS-related influences on ET-1 vasoconstriction tone. Finally, all of the subjects in our study were Caucasian adults. Given the racial and ethnic differences reported in susceptibility to, and prevalence of, MetS (26), it is prudent to view our findings within the context of the population studied.

In conclusion, the results of the present study demonstrate that the presence of the MetS is associated with higher ET-1 vasoconstrictor tone in overweight/obese adults. Moreover, the enhanced ET-1 vasoconstrictor activity with MetS is mediated by the $\mathrm{ET}_{\mathrm{A}}$ receptor subtype. Considering that the $\mathrm{ET}_{\mathrm{A}}$ receptor is the predominant $\mathrm{ET}$ receptor subtype in the coronary vasculature $(23,24)$ and ET-1 system activity is linked to atherogenesis and cardiovascular events $(9,11,19)$, increased $\mathrm{ET}_{\mathrm{A}}$ receptor-mediated ET-1 vasoconstrictor tone may be an important characteristic of the MetS that contributes to the higher coronary artery disease risk in overweight and obese adults with MetS.

\section{Acknowledgments}

We would like to thank all the subjects who participated in this study.

FUNDING

This study was supported by National Institutes of Health awards HL077450, HL076434, and UL1 TR000154 and American Heart Association award 0840167N.

\section{Abbreviations}

$\begin{array}{ll}\text { MetS } & \text { metabolic Syndrome } \\ \text { ET-1 } & \text { endothelin-1 } \\ \text { NCEP-ATP III } & \text { National Cholesterol Education Program Adult Treatment Plan III } \\ \text { FBF } & \text { forearm blood flow }\end{array}$




\section{REFERENCES}

1. Alberti KG, Zimmet P, Shaw J. Metabolic syndrome--a new world-wide definition. A Consensus Statement from the International Diabetes Federation. Diabet Med. 2006; 23:469-480. [PubMed: 16681555]

2. Cardillo C, Kilcoyne C, Waclawiw M, Cannon R, Panza J. Role of endothelin in the increased vascular tone of patients with essential hypertension. Hypertension. 1999; 33:753-758. [PubMed: 10024340]

3. Dashwood M, Tsui J. Endothelin-1 and atherosclerossis: potnetial complications associated with endothelin-receptor blockade. Atherosclerosis. 2002; 160:297-304. [PubMed: 11849651]

4. Diehl KJ, Templeton DL, Ma J, Weil BR, Greiner JJ, Stauffer BL, Desouza CA. Impaired fasting blood glucose is associated with increased endothelin-1 vasoconstrictor tone. Atherosclerosis. 2013; 229:130-133. [PubMed: 23643051]

5. Elgebaly MM, Portik-Dobos V, Sachidanandam K, Rychly D, Malcom D, Johnson MH, Ergul A. Differential effects of ET(A) and ET(B) receptor antagonism on oxidative stress in type 2 diabetes. Vascul Pharmacol. 2007; 47:125-130. [PubMed: 17597010]

6. Grundy SM, Brewer HB Jr. Cleeman JI, Smith SC Jr. Lenfant C. Definition of metabolic syndrome: report of the National Heart, Lung, and Blood Institute/American Heart Association conference on scientific issues related to definition. Arterioscler Thromb Vasc Biol. 2004; 24:e13-18. [PubMed: 14766739]

7. Haynes W, Strachan F, Gray G, Webb D. Forearm vasoconstriction to endothelin-1 is mediated by ETA and ETB receptors in vivo in humans. Journal of Cardiovascular Pharmacology. 1995; 26:S40-43. [PubMed: 8587426]

8. Hunt KJ, Resendez RG, Williams K, Haffner SM, Stern MP. National Cholesterol Education Program versus World Health Organization metabolic syndrome in relation to all-cause and cardiovascular mortality in the San Antonio Heart Study. Circulation. 2004; 110:1251-1257. [PubMed: 15326061]

9. Ihling C, Szombathy T, Bohrmann B, Brockhaus M, Schaefer HE, Loeffler BM. Coexpression of endothelin-converting enzyme-1 and endothelin-1 in different stages of human atherosclerosis. Circulation. 2001; 104:864-869. [PubMed: 11514370]

10. Ingelsson E, Sullivan LM, Fox CS, Murabito JM, Benjamin EJ, Polak JF, Meigs JB, Keyes MJ, O'Donnell CJ, Wang TJ, D'Agostino RB, Wolf PA, Vasan RS. Burden and prognostic importance of subclinical cardiovascular disease in overweight and obese individuals. Circulation. 2007; 116:375-384. [PubMed: 17620505]

11. Kelly J, Whitworth J. Endothelin-1 as a mediator in cardiovascular disease. Clinical and Experimental Pharmacology and Physiology. 1999; 26:158-161. [PubMed: 10065339]

12. Lakka HM, Laaksonen DE, Lakka TA, Niskanen LK, Kumpusalo E, Tuomilehto J, Salonen JT. The metabolic syndrome and total and cardiovascular disease mortality in middle-aged men. Jama. 2002; 288:2709-2716. [PubMed: 12460094]

13. Lohman, T.; Roche, A.; Mortorell, R. Athropometric Standardization Reference Manual. Human Kinetics; Champaign, IL: 1988.

14. Lorenzo C, Okoloise M, Williams K, Stern MP, Haffner SM. The metabolic syndrome as predictor of type 2 diabetes: the San Antonio heart study. Diabetes Care. 2003; 26:3153-3159. [PubMed: 14578254]

15. Luscher T, Barton M. Endothelins and endothelin receptor antagonists: therapeutic considerations for a novel class of cardiovascular drugs. Circulation. 2000; 102:2434-2440. [PubMed: 11067800]

16. Masaki T, Kimura S, Yanagisawa M, Goto K. Molecular and cellular mechanism of endothelin regulation. Implications for vascular function. Circulation. 1991; 89:1457-1468. [PubMed: 1655302]

17. Mather K, Mirzamohammadi B, Lteif A, Steinberg H, Baron A. Endothelin contributes to basal vascular tone and endothelial dysfunction in human obesity and type 2 diabetes. Diabetes. 2002; 51:3517-3523. [PubMed: 12453909] 
18. Matthews DR, Hosker JP, Rudenski AS, Naylor BA, Treacher DF, Turner RC. Homeostasis model assessment: insulin resistance and beta-cell function from fasting plasma glucose and insulin concentrations in man. Diabetologia. 1985; 28:412-419. [PubMed: 3899825]

19. Miyauchi T, Masaki T. Pathophysiology of endothelin in the cardiovascular system. Annual Reviews of Physiology. 1999; 61:391-415.

20. Mottillo S, Filion KB, Genest J, Joseph L, Pilote L, Poirier P, Rinfret S, Schiffrin EL, Eisenberg MJ. The metabolic syndrome and cardiovascular risk a systematic review and meta-analysis. J Am Coll Cardiol. 2010; 56:1113-1132. [PubMed: 20863953]

21. Onat A. Metabolic syndrome: nature, therapeutic solutions and options. Expert Opin Pharmacother. 2011; 12:1887-1900. [PubMed: 21756201]

22. Patel JN, Jager A, Schalkwijk C, Corder R, Douthwaite JA, Yudkin JS, Coppack SW, Stehouwer $\mathrm{CD}$. Effects of tumour necrosis factor-alpha in the human forearm: blood flow and endothelin-1 release. Clin Sci (Lond). 2002; 103:409-415. [PubMed: 12241541]

23. Pierre LN, Davenport AP. Endothelin receptor subtypes and their functional relevance in human small coronary arteries. Br J Pharmacol. 1998; 124:499-506. [PubMed: 9647474]

24. Pierre LN, Davenport AP. Relative contribution of endothelin A and endothelin B receptors to vasoconstriction in small arteries from human heart and brain. J Cardiovasc Pharmacol. 1998; 31(Suppl 1):S74-76. [PubMed: 9595405]

25. Pollock DM, Pollock JS. Endothelin and oxidative stress in the vascular system. Curr Vasc Pharmacol. 2005; 3:365-367. [PubMed: 16248780]

26. Sharma S, Malarcher AM, Giles WH, Myers G. Racial, ethnic and socioeconomic disparities in the clustering of cardiovascular disease risk factors. Ethn Dis. 2004; 14:43-48. [PubMed: 15002922]

27. Stauffer BL, Westby CM, Greiner JJ, Van Guilder GP, Desouza CA. Sex differences in endothelin-1-mediated vasoconstrictor tone in middle-aged and older adults. Am J Physiol Regul Integr Comp Physiol. 2010; 298:R261-265. [PubMed: 19939973]

28. Steinberg H, Chaker H, Leaming R, Johnson A, Brechtel G, Baron A. Obesity/insulin resistance is associated with endothelial dysfunction. Journal of Clinical Investigation. 1996; 97:2601-2610. [PubMed: 8647954]

29. Third Report of the National Cholesterol Education Program (NCEP) Expert Panel on Detection, Evaluation, and Treatment of High Blood Cholesterol in Adults (Adult Treatment Panel III) final report. Circulation. 2002; 106:3143-3421. Third. [PubMed: 12485966]

30. Touyz R, Schiffrin E. Role of endothelin in human hypertension. Canadian Journal of Physiology and Pharmacology. 2003; 81:533-541. [PubMed: 12839265]

31. Van Guilder GP, Hoetzer GL, Dengel DR, Stauffer BL, DeSouza CA. Impaired endotheliumdependent vasodilation in normotensive and normoglycemic obese adult humans. J Cardiovasc Pharmacol. 2006; 47:310-313. [PubMed: 16495771]

32. Van Guilder GP, Hoetzer GL, Greiner JJ, Stauffer BL, Desouza CA. Influence of metabolic syndrome on biomarkers of oxidative stress and inflammation in obese adults. Obesity (Silver Spring). 2006; 14:2127-2131. [PubMed: 17189537]

33. Van Guilder GP, Hoetzer GL, Smith DT, Irmiger HM, Greiner JJ, Stauffer BL, DeSouza CA. Endothelial t-PA release is impaired in overweight and obese adults but can be improved with regular aerobic exercise. Am J Physiol Endocrinol Metab. 2005; 289:E807-813. [PubMed: 15985456]

34. Van Guilder GP, Stauffer BL, Greiner JJ, Desouza CA. Impaired endothelium-dependent vasodilation in overweight and obese adult humans is not limited to muscarinic receptor agonists. Am J Physiol Heart Circ Physiol. 2008; 294:H1685-1692. [PubMed: 18281379]

35. Van Guilder GP, Westby CM, Greiner JJ, Stauffer BL, DeSouza CA. Endothelin-1 vasoconstrictor tone increases with age in healthy men but can be reduced by regular aerobic exercise. Hypertension. 2007; 50:403-409. [PubMed: 17576858]

36. Verma S, Li SH, Badiwala MV, Weisel RD, Fedak PW, Li RK, Dhillon B, Mickle DA. Endothelin antagonism and interleukin-6 inhibition attenuate the proatherogenic effects of C-reactive protein. Circulation. 2002; 105:1890-1896. [PubMed: 11997273] 
37. Weil BR, Stauffer BL, Greiner JJ, DeSouza CA. Prehypertension is associated with impaired nitric oxide-mediated endothelium-dependent vasodilation in sedentary adults. Am J Hypertens. 2011; 24:976-981. [PubMed: 21633396]

38. Weil BR, Westby CM, Van Guilder GP, Greiner JJ, Stauffer BL, DeSouza CA. Enhanced endothelin-1 system activity with overweight and obesity. Am J Physiol Heart Circ Physiol. 2011; 301:H689-695. [PubMed: 21666117]

39. World Health Organization. Definition, Diagnosis and Classification of Diabetes Mellitu and its Complications. Report of a WHO Consultation. World Health Organization; Geneva: 1999. 


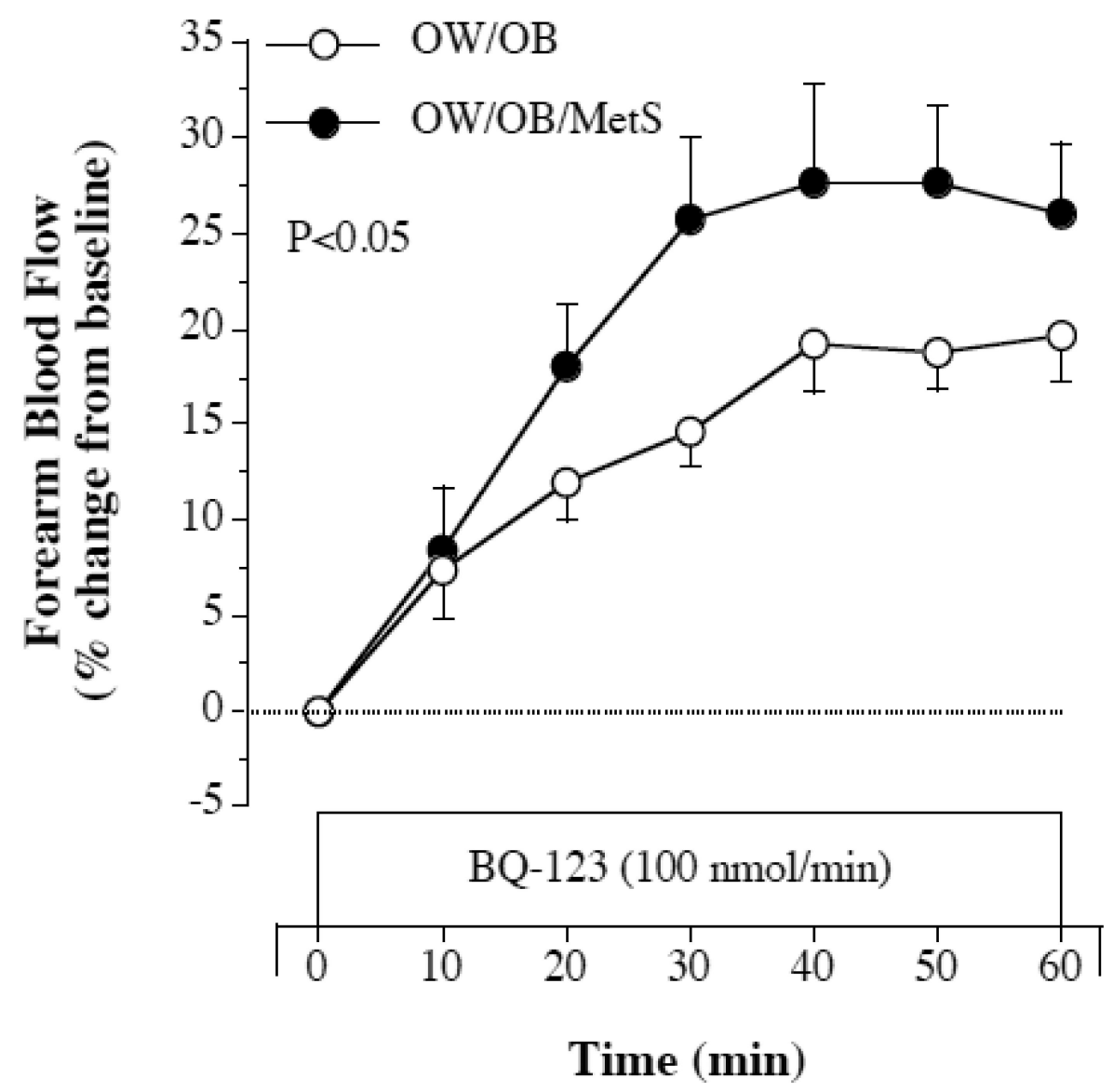

Figure 1.

Selective $\mathrm{ET}_{\mathrm{A}}$ receptor blockade. Forearm blood flow responses to BQ-123 in overweight/ obese adults without and with the MetS. The $P$ value refers to differences in forearm blood flow response between the groups. Values are expressed as means \pm SEM. 

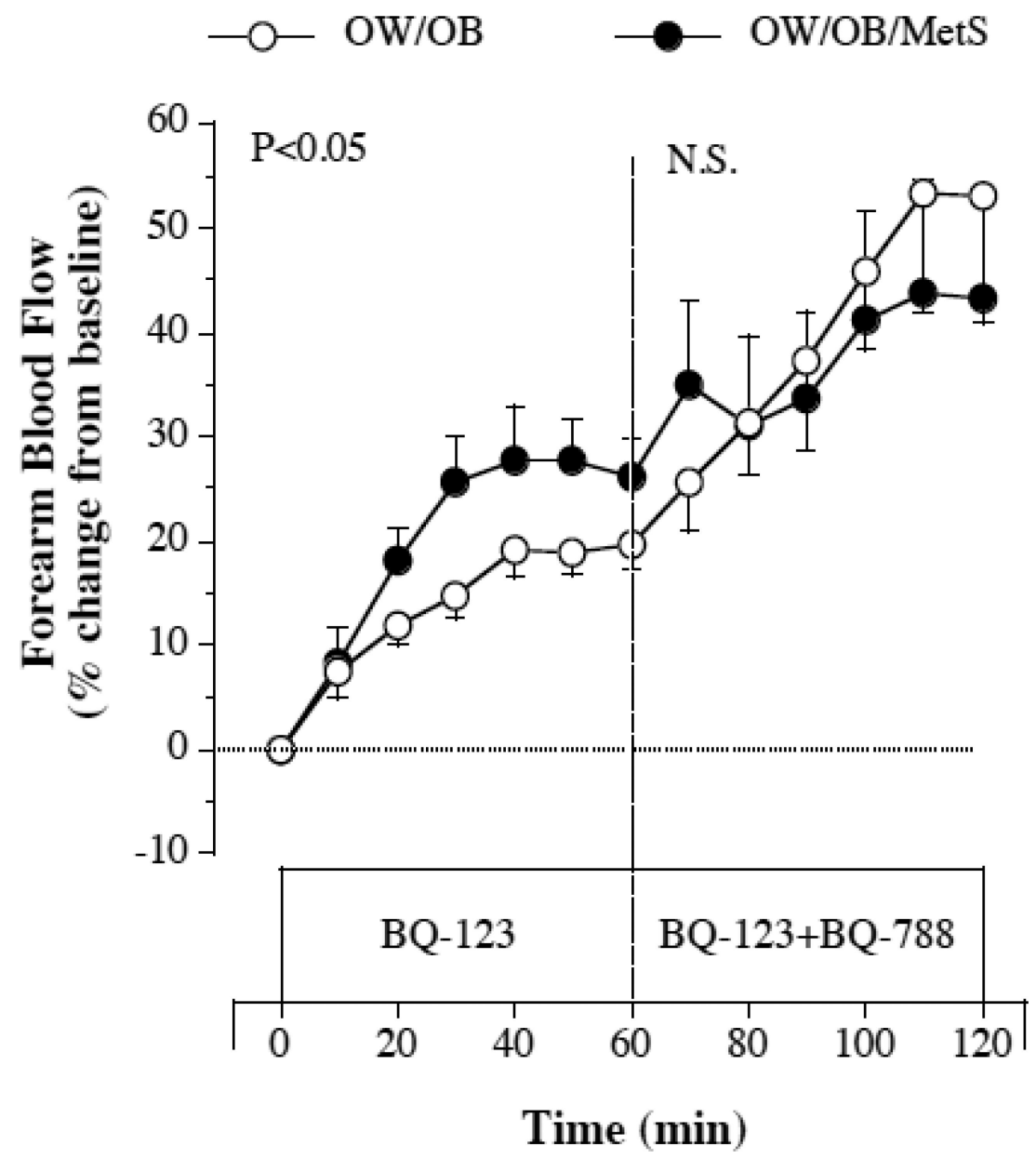

Figure 2.

Non-Selective $\mathrm{ET}_{\mathrm{A} / \mathrm{B}}$ receptor blockade. Forearm blood flow responses to $\mathrm{BQ}-123$ and BQ-123 + BQ-788 in overweight/obese adults without and with the MetS. The $P$ value refers to group differences in forearm blood flow response to selective $\mathrm{ET}_{\mathrm{A}}$ receptor antagonism (BQ-123) and dual $\mathrm{ET}_{\mathrm{A}}$ and $\mathrm{ET}_{\mathrm{B}}$ receptor blockade (BQ-123 $+\mathrm{BQ}-788$ ). Values are expressed as means \pm SEM. 


\section{Table}

Selected subject characteristics for the total population.

\begin{tabular}{lcc}
\hline Variable & Overweight/Obese $(\mathbf{n = 2 0})$ & Overweight/Obese/MetS (n=20) \\
\hline Age, $\mathrm{yr}$ & $56 \pm 2$ & $56 \pm 1$ \\
Body mass, $\mathrm{kg}$ & $88.3 \pm 3.0$ & $92.1 \pm 2.9$ \\
BMI, kg/m ${ }^{2}$ & $30.0 \pm 0.7$ & $30.4 \pm 0.6$ \\
Body fat, \% & $35.5 \pm 2.3$ & $36.2 \pm 1.8$ \\
Waist circumference, cm & $96.2 \pm 2.2$ & $100.6 \pm 1.9$ \\
Systolic BP, mmHg & $124 \pm 2$ & $132 \pm 2^{*}$ \\
Diastolic BP, mmHg & $81 \pm 1$ & $81 \pm 2$ \\
Total cholesterol, mmol/L & $5.3 \pm 0.1$ & $5.1 \pm 0.1$ \\
HDL-cholesterol, mmol/L & $1.3 \pm 0.1$ & $1.0 \pm 0.1{ }^{*}$ \\
LDL-cholesterol, mmol/L & $3.4 \pm 0.1$ & $3.3 \pm 0.1$ \\
Triglycerides, mmol/L & $1.3 \pm 0.1$ & $1.9 \pm 0.2^{*}$ \\
Glucose, mmol/L & $4.8 \pm 0.1$ & $5.2 \pm 0.2$ \\
Insulin, pmol/L & $51.9 \pm 5.4$ & $72.6 \pm 4.8^{*}$ \\
HOMA-IR & $1.9 \pm 0.2$ & $2.6 \pm 0.2^{*}$ \\
\hline
\end{tabular}

Values are mean \pm SEM. BMI, body mass index; BP, blood pressure; HOMA-IR, homeostasis model of insulin resistance.

* $\mathrm{P}<0.05$ vs. overweight/obese. 
Table 2

Selected subject characteristics for the sub-population who received non-selective $\mathrm{ET}_{\mathrm{A} / \mathrm{B}}$ receptor blockade

\begin{tabular}{lcc}
\hline Variable & Overweight/Obese $(\mathbf{n = 1 0})$ & Overweight/Obese/MetS (n=12) \\
\hline Age, yr & $57 \pm 2$ & $58 \pm 2$ \\
Body mass, kg & $86.5 \pm 3.7$ & $89.1 \pm 3.8$ \\
BMI, $\mathrm{kg} / \mathrm{m}^{2}$ & $29.3 \pm 0.7$ & $29.8 \pm 0.9$ \\
Body fat, $\%$ & $34.7 \pm 2.9$ & $37.1 \pm 2.6$ \\
Waist circumference, cm & $94.2 \pm 2.7$ & $98.4 \pm 2.7$ \\
Systolic BP, mmHg & $129 \pm 2$ & $135 \pm 1{ }^{*}$ \\
Diastolic BP, mmHg & $84 \pm 2$ & $83 \pm 2$ \\
Total cholesterol, mmol/L & $5.3 \pm 0.2$ & $5.2 \pm 0.2$ \\
HDL-cholesterol, mmol/L & $1.3 \pm 0.1$ & $1.1 \pm 0.1^{*}$ \\
LDL-cholesterol, mmol/L & $3.5 \pm 0.2$ & $3.3 \pm 0.2$ \\
Triglycerides, mmol/L & $1.1 \pm 0.1$ & $1.7 \pm 0.2^{*}$ \\
Glucose, mmol/L & $5.0 \pm 0.1$ & $5.3 \pm 0.2$ \\
Insulin, pmol/L & $49.2 \pm 7.8$ & $67.0 \pm 4.7$ \\
HOMA-IR & $1.9 \pm 0.3$ & $2.7 \pm 0.2^{*}$ \\
\hline
\end{tabular}

Values are mean \pm SEM. BMI, body mass index; BP, blood pressure; HOMA-IR, homeostasis model of insulin resistance.

* $\mathrm{P}<0.05$ vs. overweight/obese. 